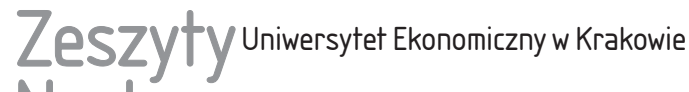 Naukowe
}

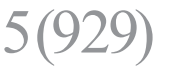

ISSN 1898-6447

Zesz. Nauk. UEK, 2014; 5 (929): 19-39

DOI: 10.15678/ZNUEK.2014.0929.0502

Joanna Mrówka

Katedra Matematyki

Uniwersytet Ekonomiczny w Krakowie

\section{Aksjomatyczna analiza sprawiedliwości dystrybutywnej Johna Rawlsa w modelu Arrowa-Debreu}

\section{Streszczenie}

Celem pracy jest przedstawienie koncepcji sprawiedliwości dystrybutywnej Johna Rawlsa oraz jej aksjomatyczna analiza w gospodarce rynkowej, reprezentowanej przez ekonomię Debreu z własnością prywatną. Wprowadzone porównania interpersonalne pozwalają na wyznaczanie jednostek najmniej uprzywilejowanych oraz na zdefiniowanie zasady dyferencji. Następnie zasada ta zostaje uogólniona do leksyminu. Tak zdefiniowane relacje sprawiedliwości, niezależne od stanów ekonomii, charakteryzują cały model ekonomii. Pozwala to na wykorzystanie konstrukcji przestrzeni modeli jako wielozakresowych systemów relacyjnych ze specjalnie zdefiniowaną charakterystyką. Odpowiednio zdefiniowane rozszerzenia systemów i ich charakterystyk ilustrują ekonomię ewolucyjną Schumpetera. W tym ujęciu można zadać pytanie, jakie warunki gwarantują zachowanie zdefiniowanych relacji sprawiedliwości dystrybutywnej. Rozwiązanie przynosi kumulatywne rozszerzenie ekonomii Debreu odpowiadające Schumpeterowskiemu ruchowi okrężnemu. Z kolei zmiany innowacyjne, będące podstawą rozwoju gospodarczego, przy zachowaniu kumulatywności zachowują poziom sprawiedliwości w sensie zasady dyferencji oraz zwiększają poziom sprawiedliwości w sensie leksyminu.

Słowa kluczowe: sprawiedliwość dystrybutywna, John Rawls, zasada dyferencji, leksymin. 


\section{Wstęp}

Jedną z ciekawszych koncepcji sprawiedliwości we współczesnej myśli społeczno-politycznej jest koncepcja sprawiedliwości Johna Rawlsa [1971]. Stąd celem pracy jest przedstawienie koncepcji sprawiedliwości dystrybutywnej Rawlsa i jej aksjomatyczna analiza [Hammond 1976] w gospodarce rynkowej, reprezentowanej przez ekonomię Debreu z własnością prywatną [Debreu 1959, Malawski 1999, 2008, Malawski i Woerter 2006]. Zdefiniowanie zasady dyferencji - jednej z kluczowych w koncepcji J. Rawlsa - wymaga wprowadzenia porównań interpersonalnych w celu wyznaczenia jednostek najmniej uprzywilejowanych. Korzystając z koncepcji ubóstwa jako deprywacji zdolności do funkcjonowania (zob. [Sen 1992, 1999, 2000, 2002]), definiuje się rozpiętość zbioru ograniczeń budżetowych (zob. [Malawski i Mrówka 2004]) pozwalającą na wyznaczenie najmniej uprzywilejowanych członków społeczeństwa, co wraz z postulatem, aby zapewnić im specjalne korzyści, stanowi jej jądro [Rawls 1971, s. 90-95]. Tak zdefiniowana relacja okazuje się niezależna od aktualnie realizowanych przez konsumentów planów konsumpcji i charakteryzuje cały model ekonomii. Ponadto zasada dyferencji może zostać uogólniona do leksyminu. Niezależność zasady dyferencji i leksyminu od stanów ekonomii Debreu pozwala na wykorzystanie konstrukcji przestrzeni modeli Debreu jako wielozakresowych systemów relacyjnych ze specjalnie zdefiniowaną charakterystyką (zob. [Malawski 1999, 2008, Malawski i Woerter 2006, Ciałowicz i Malawski 2011]). Odpowiednio określone we wspomnianych pracach rozszerzenia tych systemów i ich charakterystyk ilustrują ekonomię ewolucyjną Schumpetera [1912]. W tym ujęciu można zadać pytanie, jakie warunki gwarantują zachowanie badanych relacji sprawiedliwości dystrybutywnej. Rozwiązanie przynosi kumulatywne rozszerzenie ekonomii Debreu, w postaci ogólniejszej niż przedstawiona w pracy [Malawski i Mrówka 2004], modelujące Schumpeterowski ruch okrężny. Z kolei zmiany innowacyjne charakteryzujące rozwój gospodarczy przy zachowaniu kumulatywności zachowują poziom sprawiedliwości w sensie zasady dyferencji oraz zwiększają poziom sprawiedliwości w sensie leksyminu. Innymi słowy zmiany innowacyjne nie naruszają efektywności (w sensie Pareta) systemu gospodarczego w odniesieniu do zasad sprawiedliwości dystrybutywnej. Zaprezentowane tu wyniki stanowią rozszerzenie i uogólnienie wcześniejszych, zamieszczonych w pracy [Mrówka 2009].

Niniejszy artykuł składa się z czterech części. W następnym punkcie zaprezentowano koncepcję sprawiedliwości dystrybutywnej według J. Rawlsa. Punkt trzeci zawiera omówienie modelu ekonomii Debreu wraz z jego rozszerzeniem modelującym Schumpeterowską ekonomię ewolucyjną. W punkcie czwartym przedstawiona została analiza zasady dyferencji Rawlsa oraz jej uogólnienie do leksyminu. W części tej podane zostały również warunki gwarantujące zachowanie zdefiniowanych relacji. 


\section{Sprawiedliwość dystrybutywna według J. Rawlsa}

Koncepcja J. Rawlsa, zawarta w opublikowanym w 1971 r. dziele Theory of Justice, stanowić miała alternatywę wobec utylitaryzmu. Według J. Rawlsa sprawiedliwość jest pierwszą cnotą społecznych instytucji, więc sprzecznością byłoby czyjąkolwiek utratę wolności usprawiedliwiać wzrostem dobra stającego się udziałem innych. Wbrew temu, co dopuszcza utylitaryzm, nie można pozwalać, aby zadośćuczynieniem za wyrzeczenia narzucone nielicznym było zwiększenie sumy korzyści odnoszonych przez wielu. Ponadto, jak pisze J. Rawls [1994, s. 13], „prawda i sprawiedliwość, jako cnoty naczelne ludzkiej działalności, są bezkompromisowe".

Sprawiedliwość społeczna dla J. Rawlsa jest sposobem, w jaki główne instytucje społeczne rozdzielają prawa i obowiązki oraz dzielą płynące z nich korzyści. Przedmiotem sprawiedliwości są zatem główne instytucje społeczne jak konstytucja polityczna oraz układy społeczne i ekonomiczne. Przy takim ujęciu sprawiedliwości źródłem nierówności społecznych jest faworyzowanie określonych pozycji wyjściowych, gdyż to właśnie zajmowanie danej pozycji społecznej, nie zawsze wybranej przez jednostkę, decyduje o możliwościach korzystania z różnych przywilejów. $Z$ tego powodu J. Rawls (zob. [Kot, Malawski i Węgrzecki 2004]) koncentruje się na sformułowaniu zasad sprawiedliwości społecznej w społeczności „dobrze urządzonej” i tak buduje teorię idealnej sprawiedliwości społeczeństwa, aby dostarczyć kryterium oceny podziału dóbr wyznaczonego przez podstawową strukturę społeczną.

Budowę koncepcji sprawiedliwości J. Rawls rozpoczyna od wyznaczenia zasad, które ludzie wolni i rozumni, „mając swoje własne korzyści na uwadze przyjęliby w wyjściowej sytuacji równości jako definicję podstawowych warunków swego stowarzyszenia" [Rawls 1994, s. 23]. Te zasady regulujące wszelkie porozumienia społeczne J. Rawls nazywa sprawiedliwością jako bezstronnością (justice as fairness). Zasady sprawiedliwości jako bezstronności muszą zostać wybrane za zasłoną niewiedzy, tylko bowiem w sytuacji niewiedzy co do swoich przyszłych losów ludzie będą domagać się równości w przypisywaniu podstawowych praw i obowiązków oraz nie pozwolą na stworzenie warunków sprzyjających powstaniu nierówności społecznych i ekonomicznych. Zasłona niewiedzy jest w zamyśle J. Rawlsa odpowiednikiem stanu natury, w którym racjonalne jednostki dokonują wyboru generalnych zasad sprawiedliwości. Wyjściowym założeniem sytuacji pierwotnej jest przyjęcie, że każda jednostka jest równa w wolności, ale nie zna swojego miejsca w społeczeństwie, swojego rodowodu, zajmowanej pozycji społecznej i statusu majątkowego. Ponadto nie wie, jakie naturalne uzdolnienia przypadną jej w udziale, nie zna także swoich predyspozycji psychicznych (zob. [Karp 2004]). Ideę tę J. Rawls ilustruje przykładem: „Gdyby na przykład ktoś wiedział, że jest 
bogaty, mógłby uznać za rozumne forsowanie zasady, by różne podatki na rzecz opieki społecznej uznać za niesprawiedliwe; gdyby wiedział, że jest biedny, najprawdopodobniej zaproponowałby zasadę przeciwną" [1994, s. 32]. Zakłada się natomiast, że wiedza ogólna dotycząca zagadnień politycznych, znajomość zasad ekonomii, podstaw organizacji społecznej oraz praw psychologii jest dostępna. Dodatkowo jednostki znajdują się w tak zwanych okolicznościach sprawiedliwości (zob. [Porębski 1999]). Są to okoliczności sprawiające, że społeczna współpraca jest możliwa i konieczna. Mianowicie wszyscy są zainteresowani współpracą, gdyż daje ona korzyści, natomiast przy rozdziale tych korzyści interesy poszczególnych osób mogą się różnić i dlatego zasady sprawiedliwości są konieczne. Dopiero w tej sytuacji, pozostając za zasłoną niewiedzy, jednostki są w stanie kierować się rzeczywistą bezstronnością w wyborze zasad sprawiedliwości. Można powiedzieć, że wybór zasad sprawiedliwości jest wyborem jednomyślnym, gdyż mógłby być dokonany przez jedną, dowolnie wybraną osobę, ponieważ wszystkie jednostki znajdują się w takim samym położeniu i mają taki sam poziom wiedzy. Przyjęte zasady, normujące działania instytucji publicznych wobec obywateli we wszystkich sferach życia publicznego w państwie, uniemożliwią uprzywilejowanie lub upośledzenie kogokolwiek w wyniku działań przypadku lub wpływu społecznych okoliczności. Zasady te będą sprawiedliwe tylko wtedy, gdy zagwarantują korzyści wszystkim, a zwłaszcza najmniej uprzywilejowanym członkom społeczeństwa. W ten sposób (zob. [Kot, Malawski i Węgrzecki 2004]) teoria sprawiedliwości, poprzez wybór podstawowych zasad, łączy się z teorią racjonalnego wyboru. W tym zakresie J. Rawls postuluje regułę maksyminu. Reguła ta nakazuje stronom ustalającym zasady sprawiedliwości za zasłoną niewiedzy maksymalizować położenie osób w najgorszej sytuacji, pamiętając, iż nie wiadomo, komu ono przypadnie. Inaczej mówiąc, J. Rawls ustala w ten sposób poziom niechęci do ryzyka. Mianowicie reguła maksyminu nakłania podmiot do przejrzenia wszelkich scenariuszy oraz wyboru takiego, w którym najgorszy wynik jest najlepszy z wszystkich innych najgorszych wyników (zob. [Brighouse 2007]).

J. Rawls przedstawia teorię dóbr pierwotnych [1994, 2001] obejmującą trzy kategorie: pierwotne dobra naturalne, jak zdrowie, inteligencja czy talenty niepodlegające dystrybucji, szacunek do samego siebie - niebędący przedmiotem dystrybucji, ale zależny od dystrybucji pierwotnych dóbr społecznych oraz wspomniane pierwotne dobra społeczne - będące przedmiotem dystrybucji, w skład których wchodzą:

a) podstawowe wolności, w tym swoboda myśli, wolność sumienia;

b) swoboda poruszania się i dokonywania wyboru zawodu;

c) uprawnienia i prerogatywy urzędów publicznych;

d) dochód i bogactwo;

e) społeczna podstawa szacunku do samego siebie. 
Tak zdefiniowane pierwotne dobra społeczne powinny być rozdzielane zgodnie z dwoma zasadami sprawiedliwości (zob. [Rawls 1971, 2001, Brighouse 2007, s. 67]):

Zasada pierwsza: Każda osoba winna mieć równe niezbywalne prawo do najszerszego całościowego systemu równych podstawowych wolności, dającego się pogodzić z takim samym systemem wolności dla wszystkich.

Zasada druga: Nierówności społeczne i ekonomiczne muszą spełniać dwa warunki: po pierwsze, muszą one wiązać się z dostępnością urzędów i stanowisk dla wszystkich w warunkach autentycznej równości szans, po drugie zaś, muszą być ułożone z najwyższą korzyścią dla najbardziej upośledzonych.

Zasady te mają porządek leksykalny, tzn. zastosowanie kolejnej z reguł nie może naruszać poprzedniej. Na szczególną uwagę zasługuje część druga zasady drugiej. J. Rawls dopuszcza istnienie nierówności społeczno-ekonomicznych wtedy, gdy różnica ta działa na korzyść jednostek znajdujących się w gorszym położeniu. Jak pisze: „Urządzenie społecznych i ekonomicznych nierówności winno być takie, by było z największą korzyścią dla najmniej uprzywilejowanych i żeby nierówności te były związane z pozycjami i urzędami otwartymi dla wszystkich w warunkach autentycznej równości możliwości” [1994, s. 119]. Jest to tak zwana zasada dyferencji. Nie jest ona jednoznaczna z zasadą kompensacji, gdyż nie kładzie nacisku na wyrównanie pozycji gorzej sytuowanych kosztem lepiej usytuowanych, ale na przyjęcie takich rozwiązań, które pozwolą na stworzenie warunków, w których osiąganie lepszej pozycji przez lepiej sytuowanych poprawia lub przynajmniej nie pogarsza sytuacji najgorzej usytuowanych. Bliższa zasadzie dyferencji jest już zasada wzajemności (wzajemnych korzyści) mówiąca, że ,pomyślność każdej jednostki w oczywisty sposób zależy od systemu społecznej kooperacji, bez której nikt nie mógłby wieść zadowalającego życia" [Rawls 1994, s. 148], czy też zasada braterstwa, będąca wyrazem przekonania o potrzebie równości, szacunku, przyjaźni i solidarności. Zarazem owe warunki zapewniają - jak wskazano w kolejnym punkcie artykułu - podstawowe formy życia gospodarczego wyróżnione przez J. Schumpetera, tj. ruch okrężny i rozwój gospodarczy.

\section{Model}

Model ekonomii z własnością prywatną opisany przez G. Debreu [1959] zawiera podstawowe pojęcia teorii Arrowa-Debreu dotyczące ogólnej równowagi ekonomicznej. Pojęcia te można ująć w wielozakresowy system relacyjny łączący system produkcji z systemem konsumpcji [Malawski 1999, 2008, Malawski i Woerter 2006, Ciałowicz i Malawski 2011]. 
System produkcji jest reprezentowany przez dwuzakresowy system relacyjny:

$$
P=\left(B, \mathbf{R}^{l} ; y, p, \eta, \pi\right),
$$

gdzie:

$B=\left\{b_{1}, \ldots, b_{n}\right\}$ jest skończonym zbiorem producentów,

$\mathbf{R}^{l}$ jest $l$-wymiarową przestrzenią towarów i cen,

$y \subset B \times \mathbb{P}\left(\mathbf{R}^{\prime}\right)$ jest korespondencją zbiorów produkcji,

$p \in \mathbf{R}^{l}$ jest systemem cen,

$\eta \subset B \times \mathbb{P}\left(\mathbf{R}^{\zeta}\right)$ jest korespondencją podaży,

$\pi: B \rightarrow \mathbf{R}$ jest funkcją zysku.

Podobnie system konsumpcji jest reprezentowany przez trzyzakresowy system relacyjny

gdzie:

$$
C=\left(A, \mathbf{R}^{l}, \boldsymbol{P} ; x, e, \varepsilon, p, \beta, \varphi\right),
$$

$A=\left\{a_{1}, \ldots, a_{m}\right\}$ jest skończonym zbiorem konsumentów,

$\mathbf{R}^{l}$ jest $l$-wymiarową przestrzenią towarów i cen,

$\boldsymbol{P} \subset \mathbb{P}\left(\mathbf{R}^{2 l}\right)$ jest rodziną wszystkich relacji preferencji określonych na przestrzeni towarów $\mathbf{R}^{l}$,

$x \subset A \times \mathbb{P}\left(\mathbf{R}^{l}\right)$ jest korespondencją zbiorów konsumpcji,

$e \subset A \times \mathbf{R}^{l}$ jest odwzorowaniem zasobu początkowego,

$\varepsilon \subset A \times \mathscr{P}\left(\mathbf{R}^{2 l}\right)$ jest korespondencją, która każdemu konsumentowi $a \in A$ przypisuje relację preferencji $\preccurlyeq_{a} \in \boldsymbol{P}$, zawężoną do zbioru konsumpcji $x(a)$,

$p \in \mathbf{R}^{l}$ jest systemem cen,

$\beta \subset A \times \mathbb{P}\left(\mathbf{R}^{l}\right)$ jest korespondencją zbiorów budżetowych,

$\varphi \subset A \times \mathscr{P}\left(\mathbf{R}^{l}\right)$ jest korespondencją popytu.

Ekonomia z własnością prywatną $E_{p}$ jest połączeniem systemu produkcji $P$ i systemu konsumpcji $C$, w którym konsumenci dzielą się zyskami producentów (udziały mierzone są przez odwzorowanie $\theta$ ) oraz określony jest całkowity zasób $\omega \in \mathbf{R}^{l}$ ekonomii $E_{p}$ będący własnością konsumentów. To znaczy, że korespondencja zbiorów budżetowych $\beta \subset A \times \mathbb{P}\left(\mathbf{R}^{l}\right)$ jest zmodyfikowana dla ekonomii $E_{p}$, tak że wydatki $a$-tego konsumenta nie przekraczają wartości $w_{a}=p e(a)+$ $+\sum_{b e B} \theta_{a b} \pi_{b}(p)$. Tak więc

$$
\beta(\alpha):=\beta_{(p, e(a))}(a):=\left\{x \in x(a): p x \leq w_{a}\right\} .
$$

Zatem ekonomię z własnością prywatną $E_{p}$ można finalnie opisać w postaci:

$$
E_{p}=(P, C, \theta, \omega)
$$

gdzie:

$P$ jest systemem produkcji,

$C$ jest systemem konsumpcji, 
$\theta \subset(A \times B) \times \mathbf{R}_{+}$jest funkcją opisującą udziały konsumentów w zyskach producentów, dla każdego $(a, b) \in A \times B$ liczba $\theta_{a b}:=\theta(a, b) \in[0,1]$ mierzy udział $a$-tego konsumenta w zysku $b$-tego producenta oraz dla każdego $b \in B$, $\sum_{a \in A} \theta_{a b}=1, \omega:=\sum_{a \in A} e(a)$, czyli $\omega \in \mathbf{R}^{l}$.

Konstruuje się teraz (zob. [Malawski 1999, 2008, Malawski i Woerter 2006, Ciałowicz i Malawski 2011]) przestrzeń wskazanych modeli tak, że ustalone grupy producentów i konsumentów działające w ustalonej przestrzeni towarów $\mathbf{R}^{l}$ wyposaża się w różne charakterystyki działań, co prowadzi najpierw do definicji przestrzeni charakterystyk produkcji i przestrzeni charakterystyk konsumpcji, a potem do konstrukcji przestrzeni dla systemów z wyróżnionymi zakresami, w następujący sposób.

Oznaczmy krótko system produkcji $P$ jako $P=\left(B, \mathbf{R}^{l}, C h_{P}\right)$, gdzie $C h_{P}=(y, p$, $\eta, \pi)$ jest charakterystyką systemu produkcji $P$, i niech $\boldsymbol{C H}_{\boldsymbol{P}}$ oznacza przestrzeń wszystkich charakterystyk typu

$$
\boldsymbol{C H}_{\boldsymbol{P}}:=\left\{C h_{P}: C h_{P}=(y, p, \eta, \pi) \text { jest charakterystyką produkcji }\right\} .
$$

Definiujemy przestrzeń $\boldsymbol{P}$ wszystkich systemów produkcji z zakresem $B$ i $\mathbf{R}^{l}$ następująco:

$$
\boldsymbol{P}:=\boldsymbol{P}\left(B, \mathbf{R}^{l}\right):=\left\{P: P=\left(B, \mathbf{R}^{l}, C h_{P}\right), C h_{P} \in C \boldsymbol{H}_{P}\right\} .
$$

W ten sam sposób dla systemu konsumpcji $C$ definiujemy przestrzeń wszystkich charakterystyk konsumpcji $\boldsymbol{C H}_{\boldsymbol{C}}$ :

$$
\boldsymbol{C H}_{C}:=\left\{C h_{C}: C h_{C}=(x, e, \varepsilon, p, \beta, \varphi) \text { jest charakterystyką konsumpcji }\right\}
$$

i przestrzeń wszystkich systemów konsumpcji z zakresami $A, \mathbf{R}^{l}, \boldsymbol{P}$ :

$$
\boldsymbol{C}:=\boldsymbol{C}\left(A, \mathbf{R}^{l}, \boldsymbol{P}\right):=\left\{C: C=\left(A, \mathbf{R}^{l}, \boldsymbol{P}, C h_{C}\right), C h_{C} \in \boldsymbol{C H}_{C}\right\} .
$$

Jako rezultat, używając powyższych oznaczeń dla podsystemów produkcji i konsumpcji, możemy analogicznie zdefiniować przestrzeń $\boldsymbol{C H}_{\boldsymbol{E}_{p}}$ wszystkich charakterystyk ekonomii Debreu z własnością prywatną:

$\boldsymbol{C H}_{E_{p}}:=\left\{C h_{E_{p}}: C h_{E_{p}}=(y, p, \eta, \pi, x, e, \varepsilon, \beta, \varphi, \theta, \omega)\right.$ jest charakterystyką systemu Debreu $\}$ i przestrzeń $\boldsymbol{E}_{\boldsymbol{p}}$ wszystkich ekonomii Debreu z zakresami $B, A, \mathbf{R}^{l}, \boldsymbol{P}$ :

$$
\boldsymbol{E}_{p}:=\boldsymbol{E}_{p}\left(B, A, \mathbf{R}^{l}, \boldsymbol{P}\right):=\left\{E_{p}: E_{p}=\left(B, A, \mathbf{R}^{l}, \boldsymbol{P}, C h_{E_{p}}\right), C h_{E_{p}} \in \boldsymbol{C H}_{E_{p}}\right\} .
$$

Powyższa konstrukcja nie jest zabiegiem jedynie czysto formalnym, ale umożliwia ona pewne rozwinięcie teorii ekonomicznej w kierunku ekonomii ewolucyjnej Schumpetera [1960]. Odpowiednie rozszerzenia systemów produkcji i konsumpcji trafnie ilustrują ruch okrężny oraz rozwój gospodarczy, dwie podstawowe formy życia gospodarczego wyróżnione przez J. Schumpetera. 
Ruch okrężny (zob. [Malawski 1999]), pierwsza z form życia gospodarczego, nawiązuje do cykliczności życia gospodarczego. Jest oparty na modelu ogólnej równowagi Walrasa. Interpretowany jest jako statyka porównawcza, w ramach której system gospodarczy dąży do stanu równowagi. W tym ujęciu życie gospodarcze toczy się utartymi kanałami, w sposób ciągły, zachowując rządzące nim niezmiennie reguły. Proces ten porównać można do krążenia krwi w żywym organizmie. Wszystkie rynki dóbr są zrównoważone przez równość popytu i podaży. Uczestnicy gry rynkowej, czyli producenci i konsumenci, zachowują się pasywnie. Producenci działają $w$ ramach istniejących technologii produkcyjnych i nie wykazują zysku. Konsumenci są w stanie równowagi i ich model konsumpcji nie ulega większym zmianom. Rola pieniądza jest bierna, pełni on funkcję pośrednika wymiany.

Rozwój gospodarczy jest według J. Schumpetera [1960] drugą formą życia gospodarczego. Życie gospodarcze przyjmuje postać rozwoju, będącego nieciągłym procesem, zmieniającym jakościowo strukturę systemu gospodarczego. Kierowany jest on falami innowacji, które wytrącają go z istniejącego stanu równowagi w ten sposób, że przyszła równowaga jest zasadniczo odmienna. W ten sposób statyka, będąca punktem wyjścia analizy dynamicznej, staje się jej szczególnym przypadkiem. Za siły sprawcze tych zmian rozwojowych J. Schumpeter uznał nieznane dotąd kombinacje czynników produkcji, zwane innowacjami, realizowane przez przedsiębiorców - innowatorów. Do innowacji zaliczył wprowadzenie nowego towaru lub nowej jakości towaru, wprowadzenie nowej metody produkcji, otwarcie nowego rynku, zdobycie nowego źródła surowców oraz wprowadzenie nowej organizacji branży przemysłowej [Schumpeter 1960].

Sformalizujemy teraz przedstawione wcześniej intuicje związane z ruchem okrężnym i rozwojem gospodarczym jako podstawowymi formami życia gospodarczego, wykorzystując przy tym zmodyfikowane w stosunku do ich postaci źródłowej podanej w pracy [Malawski 1999] wersje rozszerzeń.

Niech będą dane dwa systemy produkcji: $P=\left(B, \mathbf{R}^{l}, C h_{P}\right)$, gdzie $C h_{P}=(y, p, \eta, \pi)$, oraz $P^{\prime}=\left(B^{\prime}, \mathbf{R}^{l^{\prime}}, C h_{P}{ }^{\prime}\right)$, gdzie $C h_{P}{ }^{\prime}=\left(y^{\prime}, p^{\prime}, \eta^{\prime}, \pi^{\prime}\right)$.

Definicja 1 (zob. [Ciałowicz i Malawski 2011]). System produkcji $P^{\prime}=\left(B^{\prime}\right.$, $\left.\mathbf{R}^{l^{\prime}}, C h_{P}{ }^{\prime}\right)$ jest rozszerzeniem kumulatywnym systemu produkcji $P=\left(B, \mathbf{R}^{l}, C h_{P}\right)$ (krótko: $P \subset_{c} P^{\prime}$ ), jeżeli:

1) $l \leq l^{\prime}$ i $B \subset B^{\prime}$,

2) $p \leq\left.\operatorname{proj} p^{\prime}\right|_{\mathbf{R}^{l}}$,

3) $\forall b \in B$ : (3.1) $\left.Y_{b} \subset \operatorname{proj} Y_{b}^{\prime}\right|_{\mathbf{R}^{\prime}}$,

(3.2) $\left.\eta_{b}(p) \subset \operatorname{proj}^{\prime}{ }_{b}\left(p^{\prime}\right)^{\prime}\right|_{\mathbf{R}^{\prime}}$,

(3.3) $\pi_{b}(p) \leq \pi_{b}^{\prime}\left(p^{\prime}\right)$. 
Zgodnie z definicją możliwe jest pojawienie się nowych firm (producentów) oraz nowych towarów. W szczególności w przypadku gdy $l=l^{\prime}, B=B^{\prime}$, a odpowiednie projekcje są odwzorowaniami identycznościowymi, żadne nowe firmy ani towary się nie pojawiają, jak również nie są eliminowane z procesu produkcji. Wykorzystywane są stare technologie i przy niemalejących cenach optymalne plany produkcyjne pozostają takimi, dając niemalejące zyski. Oznacza to, że rozszerzenie kumulatywne może być interpretowane jako modelujące ruch okrężny sfery produkcji, zachowuje bowiem reguły gry przypisane przez J. Schumpetera tej sferze życia gospodarczego.

Silniejszą wersję rozszerzenia kumulatywnego systemów produkcji ujmuje kolejna definicja.

Definicja 2. System produkcji $P^{\prime}=\left(B^{\prime}, \mathbf{R}^{\prime \prime}, C h_{P}^{\prime}\right)$ jest silnym kumulatywnym rozszerzeniem systemu produkcji $P=\left(B, \mathbf{R}^{l}, C h_{P}\right)$ (krótko: $\left.P \subset_{s} P^{\prime}\right)$, jeżeli $P \subset_{c} P^{\prime}$ i $P \neq P^{\prime}$.

Jak widać, definicja ta obejmuje kilka przypadków szczegółowych dotyczących zmian w stosownych zakresach lub elementach charakterystyki $C h_{P}$. Jedną z możliwości przedstawia następna definicja.

Definicja 3. Niech $P \subset_{s} P^{\prime}$. Wówczas system produkcji $P^{\prime}$ jest silnym rozszerzeniem kumulatywnym systemu $P$ (krótko: $P \subset_{c}^{\pi} P^{\prime}$ ) ze względu na funkcję zysku (oznaczenie: $\subset_{c}^{\pi}$ ), jeżeli istnieje producent $b \in B$, taki że $\pi_{b}(p)<\pi_{b}{ }^{\prime}\left(p^{\prime}\right)$.

Analogicznie określimy teraz kumulatywne rozszerzenie systemu konsumpcji (zob. [Ciałowicz i Malawski 2011]).

Niech dane będą dwa systemy konsumpcji $C=\left(A, \mathbf{R}^{l}, P, C h_{C}\right)$ i $C^{\prime}=\left(A^{\prime}, \mathbf{R}^{l^{\prime}}, P^{\prime}\right.$, $\left.C h_{C}{ }^{\prime}\right)$, gdzie $C h_{C}=(x, e, \varepsilon, p, \beta, \varphi)$ oraz $C h_{C}{ }^{\prime}=\left(x^{\prime}, e^{\prime}, \varepsilon^{\prime}, p^{\prime}, \beta^{\prime}, \varphi^{\prime}\right)$.

Definicja 4. System konsumpcji $C^{\prime}=\left(A^{\prime}, \mathbf{R}^{l^{\prime}}, P^{\prime}, C h_{C}{ }^{\prime}\right)$ jest kumulatywnym rozszerzeniem systemu konsumpcji $C=\left(A, \mathbf{R}^{l}, P, C h_{C}\right)\left(\right.$ krótko: $\left.C \subset_{c} C^{\prime}\right)$, jeżeli:

1) $l \leq l$ i $A \subset A^{\prime}$,

2) $p \leq\left.\operatorname{proj} p^{\prime}\right|_{\mathbf{R}^{l}}$,

3) $\forall a \in A$ : (3.1) $\left.X_{a} \subset \operatorname{proj} X_{a}^{\prime}\right|_{\mathbf{R}^{l}}$, przy czym $\left(x_{1 a}, x_{2 a}, \ldots, x_{l a}, 0, \ldots, 0\right) \in X_{a}^{\prime}$ dla każdego $\left(x_{1 a}, x_{2 a}, \ldots, x_{l a}\right) \in X_{a}$,

(3.2) $e_{a} \leq\left.\operatorname{proj} e_{a}^{\prime}\right|_{\mathbf{R}^{\prime}}$,

(3.3) $\left.\left.\varepsilon_{a} \subset \operatorname{proj} \varepsilon_{a}{ }^{\prime}\right|_{\mathbf{R}^{l}} \Leftrightarrow \preccurlyeq{ }_{a} \subset \preccurlyeq_{a}{ }^{\prime}\right|_{X_{a}^{2}}$,

(3.4) $\left.\beta_{a}\left(p, e_{a}\right) \subset \operatorname{proj} \beta_{a}^{\prime}\left(p^{\prime}, e_{a}^{\prime}\right)\right|_{\mathbf{R}^{l}}$,

(3.5) $\left.\varphi_{a}\left(\varepsilon_{a}, p, e_{a}\right) \subset \operatorname{proj} \varphi_{a}^{\prime}\left(\varepsilon_{a}^{\prime}, p^{\prime}, e_{a}^{\prime}\right)\right|_{\mathbf{R}^{l}} \Leftrightarrow$

$\Leftrightarrow \forall x_{a}^{*} \in \varphi_{a}\left(\varepsilon_{a}, p, e_{a}\right)$

$$
\forall x_{a}{ }^{\prime} \in \varphi_{a}^{\prime}\left(\varepsilon_{a}^{\prime}, p^{\prime}, e_{a}^{\prime}\right):\left.x_{a}^{*} \preccurlyeq{ }_{a} \operatorname{proj} x_{a}{ }^{\prime \prime}\right|_{\mathbf{R}^{\prime}} .
$$


Warunki określające kumulatywne rozszerzenie systemu konsumpcji można interpretować w następujący sposób: psychofizyczna struktura jednostek $a \in A$ nie pogarsza się, każdy konsument może ignorować nowe towary (warunek 3.1), zasoby początkowe konsumentów oraz ceny nie zmniejszają się, nie maleją też ich możliwości budżetowe, a ich potrzeby są zaspokajane co najmniej na takim samym poziomie użyteczności.

Tak jak przy rozszerzeniu kumulatywnym systemu produkcji, zdefiniować można silne rozszerzenie kumulatywne systemu konsumpcji.

Definicja 5. System konsumpcji $C^{\prime}=\left(A, \mathbf{R}^{l}, \boldsymbol{P}, C h_{C}{ }^{\prime}\right)$ jest silnym rozszerzeniem kumulatywnym systemu $C=\left(A^{\prime}, \mathbf{R}^{l}, \boldsymbol{P}, C h_{C}\right)$ (krótko: $\left.C \subset_{s} C^{\prime}\right)$, jeżeli $C \subset_{c} C^{\prime}$ i $C \neq C^{\prime}$.

Podobnie jak dla systemu produkcji, również w odniesieniu do systemu konsumpcji można rozważać szczególne przypadki silnego rozszerzenia. Omówimy tu jeden z możliwych przypadków.

Definicja 6. Niech $C \subset_{s} C^{\prime}$. Wówczas system konsumpcji $C^{\prime}$ jest silnym rozszerzeniem (kumulatywnym) systemu konsumpcji $C$ (krótko: $C \subset_{c}^{\beta} C^{\prime}$ ) ze względu na zbiory budżetowe, jeżeli istnieje konsument $a \in A$, taki że $\beta_{a}\left(p, e_{a}\right) \neq\left.\operatorname{proj} \beta_{a}^{\prime}\left(p^{\prime}, e_{a}^{\prime}\right)\right|_{\mathbf{R}^{\prime}}$.

$\mathrm{Z}$ formalnego punktu widzenia stosowne elementy systemów $P$ i $C$ są związane bądź nierównościami wektorowymi, bądź inkluzjami dla zbiorów. Rzecz jasna rozważane zmiany w systemie konsumpcji nie mogą pojawić się samoistnie, lecz dają się wyjaśnić tylko w połączeniu ze stosownymi zmianami kumulatywnymi występującymi w systemie produkcji. Uwzględnienie tego wraz z definicją kumulatywnego rozszerzenia systemu konsumpcji prowadzi w naturalny sposób do zdefiniowania rozszerzenia kumulatywnego całego systemu ekonomicznego Debreu $E_{p}$.

Niech dane będą dwa systemy ekonomiczne:

$$
E_{p}=(P, C, \theta, \varpi) \text { oraz } E_{p}^{\prime}=\left(P^{\prime}, C^{\prime}, \theta^{\prime}, \varpi^{\prime}\right), E_{p}, E_{p}^{\prime} \in \boldsymbol{E}_{p} .
$$

Definicja 7 (zob. [Ciałowicz i Malawski 2011]). System ekonomiczny $E_{p}^{\prime}$ nazywamy rozszerzeniem kumulatywnym systemu $E_{p}$ (symbolicznie: $E_{p} \subset_{c} E_{p}^{\prime}$ ), jeżeli $P \subset_{c} P^{\prime}, C \subset_{c} C^{\prime}$.

Definicja 8. System ekonomiczny $E_{p}^{\prime}$ nazywamy silnym rozszerzeniem kumulatywnym systemu $E_{p}$ (symbolicznie: $E_{p} \subset_{s} E_{p}^{\prime}$ ), jeżeli $E_{p} \subset_{c} E_{p}^{\prime}$ i $E_{p} \neq E_{p}$ '.

Odpowiednie silne rozszerzenia ze względu na dowolny zakres lub element charakterystyki systemu produkcji, jak również konsumpcji w naturalny sposób przenoszą się na silne rozszerzenie kumulatywnego systemu ekonomii. Stąd 
w szczególności będziemy używać zapisu $E_{p} \subset_{c}^{\pi} E_{p}^{\prime}$ na silne rozszerzenie kumulatywne systemu ze względu na funkcję zysku.

Sformalizujmy teraz intuicje związane z rozwojem gospodarczym według J. Schumpetera, opierając się jak poprzednio na pracach [Malawski 2008, Ciałowicz i Malawski 2011].

Niech będą dane dwa systemy produkcji: $P=\left(B, \mathbf{R}^{l}, C h_{P}\right)$ oraz $P^{\prime}=\left(B^{\prime}, \mathbf{R}^{l^{\prime}}, C h_{P}{ }^{\prime}\right)$.

Definicja 9. System produkcji $P^{\prime}=\left(B^{\prime}, \mathbf{R}^{l^{\prime}}, C h_{P}{ }^{\prime}\right)$ jest innowacyjnym rozszerzeniem systemu produkcji $P=\left(B, \mathbf{R}^{l}, C h_{P}\right)$ (krótko: $\left.P \subset_{i} P^{\prime}\right)$, jeżeli:

1) $l \leq l$,

2) $\exists b^{\prime} \in B^{\prime} \forall b \in B:$ (2.1) $\left.\operatorname{proj} Y_{b^{\prime}}\right|_{\mathbf{R}^{l}} \not \subset Y_{b}$,

(2.2) $\left.\operatorname{proj} p^{\prime}\right|_{\mathbf{R}^{l}}=p$,

(2.3) $\left.\operatorname{proj} \eta_{b^{\prime}}\left(p^{\prime}\right)\right|_{\mathbf{R}^{l}} \not \subset \eta_{b}(p)$,

(2.4) $\pi_{b}(p)<\pi_{b^{\prime}}^{\prime}\left(p^{\prime}\right)$.

Definicja 10. System ekonomiczny $E_{p}{ }^{\prime}$ nazywamy rozszerzeniem innowacyjnym systemu $E_{p}$ (symbolicznie: $E_{p} \subset_{i} E_{p}^{\prime}$ ), jeżeli $P \subset_{i} P^{\prime}$.

Definicja ta oznacza, że w systemie produkcji $P^{\prime}$ pojawia się możliwość wystąpienia co najmniej jednego nowego produktu bądź towaru, który można interpretować jako innowację będącą źródłem dodatkowego nadwyżkowego zysku niemożliwego do otrzymania w „starym” systemie produkcji $P$. Możliwe jest, że nowe towary produkowane są zarówno przez całkiem nowe firmy, jak i przez istniejące wcześniej, tylko zmodernizowane. Wymaga się, żeby w systemie $P^{\prime}$ istniał co najmniej jeden producent $b^{\prime}$, którego zdolności technologiczne wykraczają poza możliwości producentów z systemu $P$. W konsekwencji optymalne plany producenta $b^{\prime}$ nie dają się zredukować do planów realizowanych przez producentów w systemie $P$. Pomimo że ceny „starych” towarów nie zmieniają się, maksymalny zysk producenta $b^{\prime}$ jest większy od zysków możliwych do osiągnięcia przez producentów w systemie produkcji $P$. Zgodnie z terminologią J. Schumpetera wyróżnionego producenta $b^{\prime}$ można traktować jako innowatora, który osiąga zysk będący konsekwencją jego przedsiębiorczości.

Zauważmy również, że zmiany innowacyjne w systemie produkcji nie wykluczają możliwości kumulatywnych zmian dla producentów niebędących innowatorami. Pozwala to na definicję innowacyjnego rozszerzenia, w którym nieinnowatorzy zachowują zasady rozszerzenia kumulatywnego [Ciałowicz i Malawski 2011]. Niech $\hat{B}$ oznacza zbiór innowatorów.

Definicja 11. Innowacyjne rozszerzenie systemu produkcji, takie że $B \subset B^{\prime}$, zachowuje kumulatywne rozszerzenie w zbiorze nieinnowatorów $B \backslash \hat{B}$ (krótko: $\left.P \subset_{i c} P^{\prime}\right)$, jeżeli: 
1) $P \subset_{i} P^{\prime}$,

2) $\hat{P} \subset_{c} \hat{P}^{\prime}$, gdzie $\hat{P}=\left(B \backslash \hat{B}, \mathbf{R}^{l}, C h_{\hat{P}}\right), \quad \hat{P}^{\prime}=\left(B^{\prime} \backslash \hat{B}^{\prime}, \mathbf{R}^{l^{\prime}}, C h_{\hat{P}^{\prime}}\right)$.

Możliwe jest teraz podanie warunków wystarczających, aby zagwarantować kumulatywne rozszerzenie systemu przy zachodzących zmianach innowacyjnych (zob. [Ciałowicz i Malawski 2011]). Twierdzenie 1 modyfikuje wcześniejszy wynik, zastępując rozszerzenie kumulatywne systemów konsumpcji jego silną wersją ze względu na zbiory budżetowe, co znajduje zastosowanie w analizie zmian sprawiedliwości dystrybutywnej.

Niech $E_{p}=\left(A, B, \mathbf{R}^{l}, \boldsymbol{P}, C h_{P}, C h_{C}, \theta, \omega\right), E_{p}{ }^{\prime}=\left(A, B, \mathbf{R}^{l^{\prime}}, \boldsymbol{P}^{\prime}, C h_{P}{ }^{\prime}, C h_{C}{ }^{\prime}, \theta, \varpi^{\prime}\right)$.

Twierdzenie 1. Jeżeli

1) $P \subset_{i c} P^{\prime}$

2) $\forall a \in A$ : (2.1) $\left.X_{a} \subset \operatorname{proj} X_{a}^{\prime}\right|_{\mathbf{R}^{l}} \operatorname{przy} \operatorname{czym}\left(x_{1 a}, x_{2 a}, \ldots, x_{l a}, 0, \ldots, 0\right) \in X_{a}^{\prime}$ dla każdego $\left(x_{1 a}, x_{2 a}, \ldots, x_{l a}\right) \in X_{a}$,

(2.2) $e_{a} \leq\left.\operatorname{proj} e_{a}^{\prime}\right|_{\mathbf{R}^{l}}$,

(2.3) $\left.\left.\varepsilon_{a} \subset \operatorname{proj} \varepsilon_{a}{ }^{\prime}\right|_{\mathbf{R}^{l}} \Leftrightarrow \preccurlyeq{ }_{a} \subset \preccurlyeq_{a}{ }^{\prime}\right|_{X_{a}^{2}}$,

(2.4) $\sum_{k=l+1}^{l^{\prime}} p_{k}^{\prime} e_{a k}^{\prime} \geq 0$

to $C \subset_{c}^{\beta} C^{\prime}$.

Dowód. Podobnie jak w pracy [Ciałowicz i Malawski 2011] dowód przeprowadzony zostanie w dwóch częściach.

W pierwszej części niech $l<l$ '. Zgodnie z definicją 4, 5 oraz 6 wystarczy wykazać, że dla każdego konsumenta $a \in A$ zachodzą warunki:

1) $\left.\beta_{a}\left(p, e_{a}\right) \subset \operatorname{proj} \beta_{a}^{\prime}\left(p^{\prime}, e_{a}{ }^{\prime}\right)\right|_{\mathbf{R}^{l}}$ oraz $\exists a_{0} \in A: \beta_{a_{0}}\left(p, e_{a_{0}}\right) \neq\left.\operatorname{proj}_{a_{0}}{ }^{\prime}\left(p^{\prime}, e_{a_{0}}{ }^{\prime}\right)\right|_{\mathbf{R}^{l}}$

2) $\left.\varphi_{a}\left(\varepsilon_{a}, p, e_{a}\right) \subset \operatorname{proj} \varphi_{a}^{\prime}\left(\varepsilon_{a}^{\prime}, p^{\prime}, e_{a}^{\prime}\right)\right|_{\mathbf{R}^{l}}$.

Warunek 1). Rozpocznijmy od przypomnienia potrzebnych definicji zbiorów budżetowych:

$$
\begin{aligned}
& \beta_{a}\left(p, e_{a}\right)=\left\{x_{a} \in X_{a}: p x_{a} \leq p e_{a}+\sum_{b \in B} \theta_{a b} \pi_{b}(p)\right\}, \\
& \beta_{a}^{\prime}\left(p^{\prime}, e_{a}^{\prime}\right)=\left\{x_{a}^{\prime} \in X_{a}^{\prime}: p^{\prime} x_{a}^{\prime} \leq p^{\prime} e_{a}^{\prime}+\sum_{b \in B} \theta_{a b} \pi_{b}^{\prime}\left(p^{\prime}\right)\right\} \text { oraz } \\
& \left.\operatorname{proj}_{\beta^{\prime}}\left(p^{\prime}, e_{a}^{\prime}\right)\right|_{\mathbf{R}^{l}}=\left\{\left.\operatorname{proj} x_{a}^{\prime}\right|_{\mathbf{R}^{\prime}}: x_{a}^{\prime} \in \beta_{a}^{\prime}\left(p^{\prime}, e_{a}^{\prime}\right)\right\} .
\end{aligned}
$$

Niech teraz $x_{a} \in \beta_{a}\left(p, e_{a}\right)$, czyli $x_{a} \in X_{a}$ oraz $p x_{a} \leq w_{a}$. Na podstawie założenia (2.1) $x_{a}{ }^{\prime}=\left(x_{1 a}, x_{2 a}, \ldots, x_{l a}, 0, \ldots, 0\right) \in X_{a}^{\prime}$.

Korzystając z założenia $P \subset_{i c} P^{\prime}$, otrzymujemy $p=\left.\operatorname{proj} p^{\prime}\right|_{\mathbf{R}^{l}}$, co daje $w_{a} \geq p x_{a}=\left.\operatorname{proj} p^{\prime}\right|_{\mathbf{R}^{l}} x_{a}=p^{\prime} x_{a}{ }^{\prime}$. Zachowanie kumulatywności $\mathrm{w}$ zbiorze nieinnowatorów implikuje warunek $\pi_{b}(p) \leq \pi_{b}{ }^{\prime}\left(p^{\prime}\right)$ dla każdego $b \in B \backslash \hat{B}$, a dla innowatorów $\pi_{b^{\prime}}(p)<\pi_{b^{\prime}}\left(p^{\prime}\right)$ dla każdego $b^{\prime} \in \hat{B}$. W ten sposób otrzymujemy następujące nierówności: 
$\sum_{b \in B} \theta_{a b} \pi_{b}(p) \leq \sum_{b \in B} \theta_{a b} \pi_{b}{ }^{\prime}\left(p^{\prime}\right)$ dla każdego $a \in A$ oraz istnieje co najmniej jeden konsument, oznaczmy go przez $a_{0} \in A$, taki że $\sum_{b \in B} \theta_{a_{0} b} \pi_{b}(p)<\sum_{b \in B} \theta_{a_{0} b} \pi_{b}{ }^{\prime}\left(p^{\prime}\right)$. Warunek (2.2) w połączeniu z warunkiem (2.4) daje zależność $p e_{a} \leq p^{\prime} e_{a}^{\prime}$. Sumując, otrzymujemy: $w_{a} \leq w_{a}{ }^{\prime}$ dla każdego $a \in A$ oraz istnieje co najmniej jeden konsument, którego majątek wzrósł $w_{a_{0}}<w_{a_{0}}$ '. W takim razie otrzymujemy $p^{\prime} x_{a}{ }^{\prime} \leq w_{a} \leq w_{a}{ }^{\prime}$, co oznacza, że $x_{a}{ }^{\prime} \in \beta_{a}^{\prime}\left(p^{\prime}, e_{a}^{\prime}\right)$, a więc zachodzi dowodzona zależność $x_{a}=\left.\left.\operatorname{proj} x_{a}{ }^{\prime}\right|_{\mathbf{R}^{l}} \in \operatorname{proj} \beta_{a}^{\prime}\left(p^{\prime}, e_{a}^{\prime}\right)\right|_{\mathbf{R}^{\prime}}$.

W odróżnieniu od wcześniejszych etapów dowodowych wykażemy teraz, że warunek $w_{a_{0}}<w_{a_{0}}{ }^{\prime}$ implikuje $\beta_{a_{0}}\left(p, e_{a_{0}}\right) \neq$ proj $\left.\beta_{a_{0}}{ }^{\prime}\left(p^{\prime}, e_{a_{0}}{ }^{\prime}\right)\right|_{\mathbf{R}^{\prime}}$. Załóżmy nie wprost,

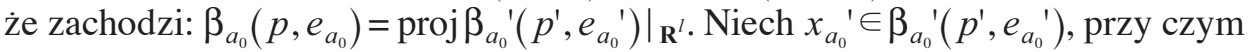

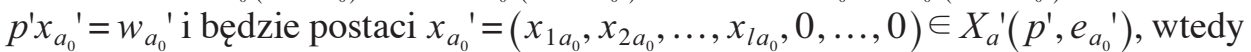
$\left.\left.\operatorname{proj} x_{a}{ }^{\prime}\right|_{\mathbf{R}^{l}} \in \operatorname{proj} \beta_{a_{0}}{ }^{\prime}\left(p^{\prime}, e_{a}{ }^{\prime}\right)\right|_{\mathbf{R}^{l}}=\beta_{a_{0}}\left(p, e_{a_{0}}\right)$, czyli proj $\left.x_{a_{0}}{ }^{\prime}\right|_{\mathbf{R}^{l}} \in \beta_{a_{0}}\left(p, e_{a_{0}}\right)$. Tak więc

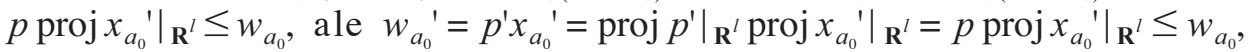
co jest sprzeczne $\mathrm{z} w_{a_{0}}<w_{a_{0}}{ }^{\prime}$ i kończy dowód warunku pierwszego.

Warunek 2). Zakładamy nie wprost, że wbrew warunkowi (3.5) w definicji 4 istnieje konsument $a \in A$, taki że $\left.\varphi_{a}\left(\varepsilon_{a}, p, e_{a}\right) \not \subset \operatorname{proj} \varphi_{a}{ }^{\prime}\left(\varepsilon_{a}{ }^{\prime}, p^{\prime}, e_{a}{ }^{\prime}\right)\right|_{\mathbf{R}^{\prime}}$, czyli że istnieje $x_{a} \in \varphi_{a}\left(\varepsilon_{a}, p, e_{a}\right)$ oraz istnieje $x_{a}{ }^{\prime} \in \varphi_{a}{ }^{\prime}\left(\varepsilon_{a}{ }^{\prime}, p^{\prime}, e_{a}{ }^{\prime}\right)$, takie że proj $\left.x_{a}{ }^{\prime}\right|_{\mathbf{R}^{l}} \prec_{a} x_{a}$. W szczególności $x_{a} \in \beta_{a}\left(p, e_{a}\right)$, a stąd wobec warunku 1) $\left.x_{a} \in \operatorname{proj} \beta_{a}^{\prime}\left(p^{\prime}, e_{a}^{\prime}\right)\right|_{\mathbf{R}^{\prime}}$. Jak wykazano w pierwszej części dowodu, wynika $\mathrm{z}$ tego, że $x_{a}{ }^{\prime \prime}=\left(x_{1 a}, x_{2 a}, \ldots, x_{l a}, 0, \ldots, 0\right) \in \beta_{a}{ }^{\prime}\left(p^{\prime}, e_{a}{ }^{\prime}\right)$, czyli $x_{a}{ }^{\prime \prime} \preccurlyeq_{a}{ }^{\prime} x_{a}{ }^{\prime}$. Korzystając z założenia (2.3) $\left.\preccurlyeq_{a}{ }^{\prime}\right|_{X_{a}^{2}} \subset \preccurlyeq_{a}$, otrzymujemy $x_{a}=\left.\operatorname{proj} x_{a}{ }^{\prime \prime}\right|_{\mathbf{R}^{l}} \preccurlyeq_{a}$ proj $\left.x_{a}{ }^{\prime}\right|_{\mathbf{R}^{l}}$, co jest sprzeczne z założeniem $\left.\operatorname{proj} x_{a}{ }^{\prime}\right|_{\mathbf{R}^{l}} \prec_{a} x_{a}$.

Część druga, dla $l=l$ '. W przypadku takiej samej ilości towarów dowód jest analogiczny przy zastąpieniu projekcji odwzorowaniami identycznościowymi.

\section{Zasada dyferencji i leksymin}

Ekonomia Debreu z własnością prywatną wydaje się trafnym kontekstem podjęcia dyskusji na temat sprawiedliwości dystrybutywnej J. Rawlsa przedstawionej w punkcie drugim. Mianowicie model Arrowa-Debreu trafnie ujmuje „sytuację pierwotną", w której ustala się reguły sprawiedliwości dystrybutywnej, pomijając strukturę socjalną społeczeństwa zgodnie z postulowaną przez J. Rawlsa zasłoną niewiedzy. Porównania interpersonalne dokonywane są przez zewnętrznego obserwatora, który nie faworyzuje żadnych jednostek, bezstronnie oceniając wyłącznie pozycję każdego z konsumentów.

Aby przeanalizować interesujący nas problem sprawiedliwości dystrybutywnej, zaczniemy od ogólnego schematu porównań interpersonalnych. Zapis 
$(i, x) \geq_{k}(j, y)$ może być interpretowany jako osąd etyczny osoby $k$ postaci: „bycie osobą $i$ w stanie $x$ jest nie gorsze od bycia osobą $j \mathrm{w}$ stanie $y$ " [Hammond 1976, s. 795]. Sformułowanie to będzie rozważane w dwóch aspektach. Po pierwsze, społeczeństwo zostanie zawężone do zbioru $A$ konsumentów ekonomii $E_{p}$, a porównania zostaną zredukowane do planów konsumpcji występujących w stanach $\left(\left(x_{a}\right),\left(y_{b}\right)\right) \in M$ tej ekonomii, takich że $x_{a} \in X_{a}, y_{b} \in Y_{b}$ oraz $\sum_{a \in A} x_{a}-\sum_{b \in B} y_{b} \leq \omega$. Po drugie, badany osąd etyczny będzie dokonywany przez zewnętrznego obserwatora, który porówna pozycje członków społeczeństwa.

Z pomocą przychodzi tu też Senowska koncepcja funkcjonowań jako „bycia i działania" (being and doing) (zob. [Sen 1992, 2000]), która zostaje tu zredukowana do zbiorów budżetowych $\beta(a)$ reprezentujących zbiory zdolności do funkcjonowania (capabilities) [Malawski i Mrówka 2004]. Dokonane uproszczenie, wbrew pozorom, nie jest zbyt drastyczne, gdyż ograniczamy naszą analizę do elementarnych funkcjonowań [Sen 1992, s. 39; 2000, s. 55], jak prawidłowe odżywianie, odpowiednia odzież, schronienie, uniknięcie chorób i przedwczesnej śmierci, które mogą być zapewnione przez realizację odpowiednich planów konsumpcji w przestrzeni towarów i cen $\mathbf{R}^{l}$, na której zbudowana jest ekonomia Debreu.

Aby ocenić zatem położenie konsumenta, należy uwzględnić zarówno jego majątek początkowy $w_{a}$, jak i jego strukturę psychofizyczną określoną przez zbiór $X_{a}$. W tym kontekście można zdefiniować krytyczną wartość majątku umożliwiającą konsumentowi przetrwanie i egzystencję jako: $w_{a}^{\min }=\min _{x \in X_{a}} p x$ (zob. [Malawski i Mrówka 2004]). Ta wartość wyznacza zbiór absolutnego ubóstwa będący zbiorem planów konsumpcji, których wartość jest równa minimalnej wartości umożliwiającej konsumentowi funkcjonowanie:

$$
X_{a}^{\min }=\left\{x_{a} \in X_{a}: p x_{a}=w_{a}^{\min }\right\} .
$$

Podane uwagi prowadzą nas do konstrukcji wskaźnika pozycji konsumenta, zwanego rozpiętością zbioru ograniczeń budżetowych. Wskaźnik pozycji $a_{i}$-tego konsumenta, oznaczany jako odległość $d$, jest różnicą między wartością majątku konsumenta a krytyczną wartością majątku umożliwiającą funkcjonowanie (zob. [Malawski i Mrówka 2004]):

$$
d^{a_{i}}=w_{a_{i}}-w_{a_{i}}^{\min } .
$$

Oczywiście dla najmniej uprzywilejowanego członka społeczeństwa $a^{-} \in A$ rozpiętość zbioru ograniczeń budżetowych może spełniać warunek: $d^{a^{-}}=0$. Odległość $d$ pozwala na porównywanie pozycji konsumentów, tak więc im większa rozpiętość zbioru ograniczeń budżetowych, tym lepsza pozycja konsumenta.

Formalnie definiujemy: 
Definicja 12 (zob. [Malawski i Mrówka 2004]). Niech będzie danych dwóch konsumentów $a_{i}, a_{j} \in A$ realizujących odpowiednio plany konsumpcji $x_{a_{i}}, x_{a_{j}}$. Mówimy, że konsument $a_{i}$ jest w porównaniu z konsumentem $a_{j}$ :

1) w gorszym położeniu (pozycji) (symbolicznie: $\left(a_{i}, x_{a_{i}}\right)<\left(a_{j}, x_{a_{j}}\right)$ ), jeżeli $d^{a_{i}}<d^{a_{j}}$

2) w takiej samej pozycji (symbolicznie: $\left(a_{i}, x_{a_{i}}\right)=\left(a_{j}, x_{a_{j}}\right)$ ), jeżeli $d^{a_{i}}=d^{a_{j}}$,

3) w nie lepszym położeniu (pozycji) (symbolicznie: $\left(a_{i}, x_{a_{i}}\right) \leq\left(a_{j}, x_{a_{j}}\right)$ ), jeżeli $d^{a_{i}} \leq d^{a_{j}}$.

Łatwo zauważyć, że pozycja konsumenta zdefiniowana powyżej jest niezależna od wyboru stanu $\left(\left(x_{a}\right),\left(y_{b}\right)\right) \in M$, co usprawiedliwia brak uwzględnienia planów produkcji w definicji oraz sprawia, że relacja ta charakteryzuje całą ekonomię $E_{p}$. Zatem dalej w pracy stany $\left(\left(x_{a}\right),\left(y_{b}\right)\right) \in M,\left(\left(x_{a}^{\prime}\right),\left(y_{b}^{\prime}\right)\right) \in M^{\prime}$ będą odnosiły się odpowiednio do odrębnych ekonomii $E_{p}, E_{p}^{\prime}$ i będziemy zapisywać: $\left(a_{i}, E_{p}\right)=\left(a_{j}, E_{p}^{\prime}\right)$, $\left(a_{i}, E_{p}\right)<\left(a_{i}, E_{p}^{\prime}\right),\left(a_{i}, E_{p}\right) \leq\left(a_{j}, E_{p}^{\prime}\right)$ itd.

Zaprezentowane rozważania prowadzą do teorii sprawiedliwości dystrybutywnej Rawlsa [1971]. Oparta na zasadzie maksyminu, czy innymi słowy zasadzie dyferencji, może być interpretowana jako nadanie pierwszeństwa najmniej uprzywilejowanemu [Roemer 1996, s. 282]. W naszym ujęciu zasada dyferencji może być przedstawiona w dwóch wersjach, standardowej [Hammond 1976] i słabej. Odnoszą się one do sytuacji, w której stan $\left(\left(x_{a}{ }^{\prime}\right),\left(y_{b}{ }^{\prime}\right)\right)$ ekonomii $E_{p}^{\prime}$ zapewnia większą (nie mniejszą) korzyść najmniej uprzywilejowanemu w stanie $\left(\left(x_{a}\right),\left(y_{b}\right)\right)$ ekonomii $E_{p}$. Tak więc:

Definicja 13 (zob. [Malawski i Mrówka 2004])

1) Mówimy, że stan $\left(\left(x_{a}^{\prime}\right),\left(y_{b}^{\prime}\right)\right)$ jest bardziej $d p$-sprawiedliwy (sprawiedliwy w sensie zasady dyferencji) od stanu $\left(\left(x_{a}\right),\left(y_{b}\right)\right)$ (symbolicznie: $\left(\left(x_{a}\right),\left(y_{b}\right)\right)<_{d p}\left(\left(x_{a}^{\prime}\right)\right.$, $\left.\left.\left(y_{b}^{\prime}\right)\right)\right)$, jeżeli:

$$
\forall a \in A\left(a_{0}, x_{a_{0}}\right) \leq\left(a, x_{a}\right) \Rightarrow \forall a \in A\left(a_{0}, x_{a_{0}}\right)<\left(a, x_{a}{ }^{\prime}\right) .
$$

2) Mówimy, że stan $\left(\left(x_{a}^{\prime}\right),\left(y_{b}^{\prime}\right)\right)$ jest co najmniej tak $d p$-sprawiedliwy (sprawiedliwy w sensie zasady dyferencji) jak stan $\left(\left(x_{a}\right),\left(y_{b}\right)\right)$ (symbolicznie: $\left(\left(x_{a}\right),\left(y_{b}\right)\right) \leq_{d p}\left(\left(x_{a}^{\prime}\right)\right.$, $\left.\left.\left(y_{b}^{\prime}\right)\right)\right)$, jeżeli:

$$
\forall a \in A\left(a_{0}, x_{a_{0}}\right) \leq\left(a, x_{a}\right) \Rightarrow \forall a \in A\left(a_{0}, x_{a_{0}}\right) \leq\left(a, x_{a}{ }^{\prime}\right) .
$$

Tutaj $a_{0} \in A$ jest konsumentem w najgorszym położeniu w stanie $\left(\left(x_{a}\right),\left(y_{b}\right)\right)$, a relacja $<_{d p}\left(\leq_{d p}\right)$ oznacza, że każdy konsument $a \in A$ ma się lepiej (nie gorzej) w stanie $\left(\left(x_{a}{ }^{\prime}\right),\left(y_{b}{ }^{\prime}\right)\right)$ niż konsument $a_{0}$ w stanie $\left(\left(x_{a}\right),\left(y_{b}\right)\right)$.

Oczywiście zasada dyferencji (warunek 1) implikuje słabą wersję (warunek 2).

Ponownie relacje $<_{d p}, \leq_{d p}$ charakteryzują cały system $E_{p}, E_{p}$ ', niezależnie od stanów $\left(\left(x_{a}\right),\left(y_{b}\right)\right),\left(\left(x_{a}^{\prime}\right),\left(y_{b}^{\prime}\right)\right)$. Możemy zatem powiedzieć, że ekonomia $E_{p}^{\prime}$ jest 
sprawiedliwsza (nie mniej sprawiedliwa) od ekonomii $E_{p}$ w sensie (słabej) zasady dyferencji, zapisując odpowiednio: $E_{p}<_{d p} E_{p}^{\prime}\left(E_{p} \leq_{d p} E_{p}{ }^{\prime}\right)$. Warunek 2 uwzględnia szczególny przypadek, gdy $d^{a_{0}}=d^{\prime a_{0}}$, oznaczany: $E_{p}={ }_{d p} E_{p}^{\prime}$.

Głównym problemem jest teraz ustalenie, jakie związki pomiędzy ekonomiami gwarantują zachowanie relacji $d p$-sprawiedliwości. Rozwiązanie przynosi zdefiniowane w trzecim punkcie artykułu rozszerzenie kumulatywne ekonomii Debreu.

Niech dane będą dwie ekonomie: $E_{p}=\left(A, B, \mathbf{R}^{l}, \boldsymbol{P}, C h_{P}, C h_{C}, \theta, \omega\right)$, $E_{p}{ }^{\prime}=\left(A, B, \mathbf{R}^{l}, \boldsymbol{P}^{\prime}, C h_{P}{ }^{\prime}, C h_{C}{ }^{\prime}, \theta, \omega^{\prime}\right)$. W przeciwieństwie do ujęcia przedstawionego w [Malawski i Mrówka 2004] dopuszczamy tu pojawienie się nowych towarów.

Twierdzenie 2. Jeżeli $E_{p} \subset_{c} E_{p}$ ', to $E_{p} \leq_{d p} E_{p}$ '.

Dowód. Niech $a_{0}$ będzie konsumentem w najgorszym położeniu w ekonomii $E_{p}$ w stanie $\left(\left(x_{a}\right),\left(y_{b}\right)\right)$, czyli dla każdego konsumenta $a \in A$ zachodzi $\left(a_{0}, x_{a_{0}}\right) \leq\left(a, x_{a}\right)$, to jest $d^{a_{0}} \leq d^{a}$. Zauważmy, że odległość $d$ można zapisać W następujący sposób: $d^{a}=p\left(x_{a}{ }^{*}-x_{a}^{\min }\right)$, gdzie $x_{a}{ }^{*}$ oznacza dowolny koszyk towarów maksymalizujący wydatki w zbiorze ograniczeń budżetowych $\beta_{a}$, czyli $p x_{a}^{*}=w_{a}$, a $x_{a}^{\min }$ oznacza koszyk towarów minimalizujący wydatki w zbiorze konsumpcji $X_{a}$, czyli plan konsumpcji ze zbioru absolutnego ubóstwa, tak więc $p x_{a}^{\min }=w_{a}^{\min }$. Wektory $x_{a}{ }^{*}, x_{a}^{\min } \in \mathbf{R}^{l}$ przedstawiamy w postaci: $x_{a}^{*}=\left(x_{a 1}^{*}, \ldots, x_{a l}^{*}\right), x_{a}^{\min }=\left(x_{a 1}^{\min }, \ldots, x_{a l}^{\min }\right)$.

Zachodzą następujące nierówności:

1) $p^{\prime} x_{a}^{\min } \leq p^{\prime}\left(x_{a 1}^{\min }, \ldots, x_{a l}^{\min }, 0, \ldots, 0\right)$

2) $p^{\prime} x_{a} *^{\prime} \geq p^{\prime}\left(x_{a 1} *, \ldots, x_{a l} *, 0, \ldots, 0\right)$

Dla dowodu pierwszej z nich zauważmy, że jeżeli $x_{a}^{\min }=\left(x_{a 1}^{\min }, \ldots, x_{a l}^{\min }\right) \in X_{a}$, to na mocy kumulatywności (definicja 4 , warunek 3.1) $\left(x_{a 1}^{\min }, \ldots, x_{a l}^{\min }, 0, \ldots, 0\right) \in X^{\prime}{ }_{a}$, czyli konsument jest w stanie funkcjonować bez nowych towarów. Warunek: $\left.X_{a} \subset \operatorname{proj} X_{a}^{\prime}\right|_{\mathbf{R}^{\prime}}$ gwarantuje z kolei, że w obrębie starych towarów kondycja psychofizyczna konsumenta się nie pogarsza. Tak więc wartość najtańszego koszyka towarów ze zbioru $\beta_{a}^{\prime}\left(p^{\prime}, e_{a}^{\prime}\right)$ przy systemie cen $p^{\prime}$ na pewno nie przekracza wartości najtańszego koszyka z ekonomii $E_{p}$ przy nowym systemie cen $p^{\prime}$.

Nierówność 2) jest konsekwencją warunku $\left.\beta_{a}\left(p, e_{a}\right) \subset \operatorname{proj} \beta_{a}^{\prime}\left(p^{\prime}, e_{a}^{\prime}\right)\right|_{\mathbf{R}^{\prime}}$, który oznacza, że konsument w ekonomii $E_{p}{ }^{\prime}$ jest w stanie zrealizować koszyk towarów, na który było go stać w ekonomii $E_{p}$, przy rezygnacji z zakupu nowych towarów.

Stąd otrzymujemy: $d^{a_{1}}=p^{\prime} x_{a}^{* \prime}-p^{\prime} x_{a}^{\min } \geq p^{\prime}\left(x_{a 1} *-x_{a 1}^{\min }, \ldots, x_{a l} *-x_{a l}^{\min }, 0, \ldots, 0\right)=$ $=\left.p^{\prime}\right|_{\mathbf{R}^{\prime}}\left(x_{a}^{*}-x_{a}^{\mathrm{min}}\right)$, pamiętając, że przy rozszerzeniu kumulatywnym zachodzi: $p \leq\left.\operatorname{proj} p^{\prime}\right|_{\mathbf{R}^{l}}$. Stąd też mamy: $\left.p^{\prime}\right|_{\mathbf{R}^{l}}\left(x_{a}{ }^{*}-x_{a}^{\min }\right) \geq p\left(x_{a}{ }^{*}-x_{a}^{\min }\right)=d^{a}$. Nierówności te zachodzą dla każdego $a \in A$. Podsumowując, otrzymujemy $d^{a_{0}} \leq d^{a} \leq d^{\prime a}$.

Koncepcja sprawiedliwości dystrybutywnej Rawlsa zbudowana na zasadzie dyferencji może być teraz wzmocniona i uogólniona do leksyminu [Sen 1970, 
Hammond 1976]. Porządek leksykograficzny, w skrócie leksymin lub zasada leksyminu, używając porównań interpersonalnych, znajduje jednostki najmniej uprzywilejowane, zasługujące na specjalne traktowanie. Aby zdefiniować leksymin, każdemu konsumentowi $a_{i}$ realizującemu plan konsumpcji $x_{a_{i}}$ przypisujemy porządkowy numer $r\left(a_{i}, x_{a_{i}}\right)$ tak, że osoby mniej uprzywilejowanie mają mniejsze numery od osób bardziej uprzywilejowanych. Do numerowania używamy liczb całkowitych od 1 do $m$. Jeżeli dwie lub więcej osób jest w tej samej sytuacji, numery przypisujemy dowolnie, nie będzie to miało wpływu na uporządkowanie przez tę relację. Numer nadaje osobie pierwszeństwo: osoby z małymi numerami będą przed osobami z numerami większymi, a osoba z numerem pierwszym otrzymuje pierwszeństwo przed wszystkimi. Niech $d^{r}=d^{a_{r\left(a_{i} x_{\left.a_{i}\right)}\right.} \text { oznacza }}$ rozpiętość zbioru budżetowego konsumenta o numerze $r$. Z definicji $d^{r+1} \geq d^{r}$. Aby zdecydować, który z dwóch stanów jest bardziej sprawiedliwy, rozpoczynamy od porównywania osób najmniej uprzywilejowanych w obu stanach. Zatem najpierw porównujemy rozpiętość zbioru budżetowego w najgorszej sytuacji w $\left(\left(x_{a}\right),\left(y_{b}\right)\right)$ $\mathrm{z}$ rozpiętością zbioru budżetowego w najgorszej sytuacji w $\left(\left(x_{a}{ }^{\prime}\right),\left(y_{b}{ }^{\prime}\right)\right)$. Stan z lepszą sytuacją (większą rozpiętością) najmniej uprzywilejowanego jest bardziej sprawiedliwy. Jeżeli badane rozpiętości są równe, porównujemy konsumentów z numerami 2, itd.

Idea ta jest sformalizowana w definicji:

Definicja 14 (zob. [Malawski i Mrówka 2004])

1) Mówimy, że stan $\left(\left(x_{a}{ }^{\prime}\right),\left(y_{b}{ }^{\prime}\right)\right)$ jest bardziej $l$-sprawiedliwy (sprawiedliwy w sensie leksyminu) od stanu $\left(\left(x_{a}\right),\left(y_{b}\right)\right)$ (symbolicznie: $\left.\left(\left(x_{a}\right),\left(y_{b}\right)\right)<_{l}\left(\left(x_{a}{ }^{\prime}\right),\left(y_{b}{ }^{\prime}\right)\right)\right)$, jeżeli

$$
\exists k \geq 1 d^{i}=d^{\prime i} \text { dla } i=1, \ldots, k-1 \text { oraz } d^{k}<d^{\prime k} .
$$

2) Mówimy, że stan $\left(\left(x_{a}{ }^{\prime}\right),\left(y_{b}{ }^{\prime}\right)\right)$ jest tak samo $l$-sprawiedliwy (sprawiedliwy w sensie leksyminu) jak stan $\left(\left(x_{a}\right),\left(y_{b}\right)\right)$ (symbolicznie: $\left.\left(\left(x_{a}\right),\left(y_{b}\right)\right)={ }_{l}\left(\left(x_{a}{ }^{\prime}\right),\left(y_{b}{ }^{\prime}\right)\right)\right)$, jeżeli

$$
d^{i}=d^{\prime i} \text { dla } i=1, \ldots, m \text {. }
$$

3) Mówimy, że stan $\left(\left(x_{a}{ }^{\prime}\right),\left(y_{b}{ }^{\prime}\right)\right)$ jest co najmniej tak $l$-sprawiedliwy (sprawiedliwy w sensie leksyminu) jak stan $\left(\left(x_{a}\right),\left(y_{b}\right)\right)$ (symbolicznie: $\left(\left(x_{a}\right),\left(y_{b}\right)\right) \leq_{l}\left(\left(x_{a}{ }^{\prime}\right)\right.$, $\left.\left.\left(y_{b}{ }^{\prime}\right)\right)\right)$, jeżeli

$$
\left(\left(x_{a}\right),\left(y_{b}\right)\right)<_{l}\left(\left(x_{a}{ }^{\prime}\right),\left(y_{b}{ }^{\prime}\right)\right) \vee\left(\left(x_{a}\right),\left(y_{b}\right)\right)=_{l}\left(\left(x_{a}{ }^{\prime}\right),\left(y_{b}{ }^{\prime}\right)\right) .
$$

Relacja zdefiniowana w ten sposób jest ponownie niezależna od wyboru odpowiednich stanów. Zatem charakteryzuje ona całe ekonomie i przy dowolnych stanach $\left(\left(x_{a}\right),\left(y_{b}\right)\right) \in M,\left(\left(x_{a}^{\prime}\right),\left(y_{b}^{\prime}\right)\right) \in M^{\prime}$ mamy: 
1) $E_{p}<_{l} E_{p}^{\prime} \Leftrightarrow\left(\left(x_{a}\right),\left(y_{b}\right)\right)<_{l}\left(\left(x_{a}^{\prime}\right),\left(y_{b}^{\prime}\right)\right)$

2) $E_{p}={ }_{l} E_{p}^{\prime} \Leftrightarrow\left(\left(x_{a}\right),\left(y_{b}\right)\right)={ }_{l}\left(\left(x_{a}^{\prime}\right),\left(y_{b}^{\prime}\right)\right)$

3) $E_{p} \leq_{l} E_{p}^{\prime} \Leftrightarrow\left(\left(x_{a}\right),\left(y_{b}\right)\right) \leq_{l}\left(\left(x_{a}^{\prime}\right),\left(y_{b}^{\prime}\right)\right)$.

Ekonomia $E_{p}^{\prime}$ jest więc odpowiednio bardziej $l$-sprawiedliwa niż, tak samo $l$-sprawiedliwa lub co najmniej tak $l$-sprawiedliwa jak ekonomia $E_{p}$.

Związek pomiędzy zasadą dyferencji a leksyminem podaje lemat 1.

Lemat 1. $E_{p}<_{d p} E_{p}{ }^{\prime} \Rightarrow E_{p}<_{l} E_{p}{ }^{\prime}$.

Dowód. $E_{p}<_{d p} E_{p}^{\prime}$ implikuje $d^{a_{0}}<d^{\prime a}$ dla każdego $a \in A$. Oznacza to, że istnieje $k=1$ takie, że $d^{1}<d^{11}$.

Analogicznie jak dla relacji $d p$-sprawiedliwości można odpowiedzieć na pytanie, jaka relacja między ekonomiami gwarantuje zachowanie relacji $l$-sprawiedliwości. Również w tym wypadku wystarczy rozszerzenie kumulatywne ekonomii Debreu:

Twierdzenie 3. Jeżeli $E_{p} \subset_{c} E_{p}$ ', to $E_{p} \leq_{l} E_{p}$ '.

Dowód. Analogicznie jak w dowodzie twierdzenia 2 otrzymujemy dla każdego konsumenta $a \in A$ zależność $d^{a} \leq d^{\prime a}$. Ponieważ sytuacja każdego konsumenta w ekonomii $E_{p}{ }^{\prime}$ jest co najmniej tak samo dobra jak w ekonomii $E_{p}$, zachodzi pożądana relacja: $E_{p} \leq_{l} E_{p}$.

Aby poprawić stopień, poziom czy też jakość $l$-sprawiedliwości, potrzebne jest silne (kumulatywne) rozszerzenie $E_{p}$ ze względu na funkcję zysku. W przypadku takiej samej ilości towarów odpowiednie twierdzenie zaprezentowano w [Malawski i Mrówka 2004]. Następująca wersja jest uogólnieniem dopuszczającym zwiększenie ilości towarów.

Twierdzenie 4. Jeżeli $E_{p} \subset{ }_{c}^{\pi} E_{p}^{\prime}$, to $E_{p}<{ }_{l} E_{p}^{\prime}$.

Dowód. Niech $E_{p} \subset{ }_{c} E_{p}^{\prime}$ oraz $\pi_{b}(p)<\pi_{b}^{\prime}\left(p^{\prime}\right)$ dla producenta $b \in B$. Stąd istnieje co najmniej jeden konsument $a \in A$ taki, że $\theta_{a_{k} b} \pi_{b}(p)<\theta_{a_{k} b} \pi_{b}{ }^{\prime}\left(p^{\prime}\right)$, gdzie $k$ oznacza liczbę całkowitą przypisaną do $a_{k}$-tego konsumenta przez relację $<_{l} \mathrm{w} E_{p}$. Zatem $w_{a_{k}}<w_{a_{k}}{ }^{\prime}$ i $d^{a_{k}}<d^{\prime a_{k}}$, ale dla $a \neq a_{k}$, jak w dowodzie twierdzenia 3, zachodzi $d^{a} \leq d^{\prime a}$. Istnieje więc $k^{\prime}: 1 \leq k^{\prime} \leq k$, takie że $d^{i}=d^{\prime i}$ dla $i=1, \ldots, k^{\prime}-1$ i $d^{k^{\prime}}<d^{\prime k^{\prime}}$, tzn. $E_{p}<{ }_{l} E_{p}^{\prime}$.

Zachodzi również zależność opisana następującym twierdzeniem:

Twierdzenie 5. Jeżeli $C \subset_{c}^{\beta} C$, to $E_{p}<_{l} E_{p}$ '.

Dowód. Ponieważ istnieje co najmniej jeden konsument $a_{k} \in A$, taki że $\beta_{a_{k}}\left(p, e_{a_{k}}\right) \neq\left.\operatorname{proj} \beta_{a_{k}}{ }^{\prime}\left(p^{\prime}, e_{a_{k}}{ }^{\prime}\right)\right|_{\mathbf{R}^{\prime}}$, czyli $w_{a_{k}}<w_{a_{k}}{ }^{\prime}$, przy jednocześnie zachodzącym dla wszystkich konsumentów $a \in A$ warunku $d^{a} \leq d^{\prime a}$, będącym kon- 
sekwencją kumulatywnego rozszerzenia. Dlatego też zachodzi $d^{a_{k}}<d^{a_{k}}$. Istnieje zatem $k^{\prime}: 1 \leq k^{\prime} \leq k$, takie że $d^{i}<d^{\prime i}$ dla $i=1, \ldots, k^{\prime}-1$ i $d^{k^{\prime}}<d^{\prime k^{\prime}}$, tzn. $E_{p}<_{l} E_{p}^{\prime}$.

Podsumowując, Schumpeterowski ruch okrężny modelowany przez kumulatywne rozszerzenie ekonomii zachowuje poziom zarówno $d p$-sprawiedliwości, jak i $l$-sprawiedliwości, natomiast silne rozszerzenie ekonomii ze względu na funkcję zysku czy też silne rozszerzenie kumulatywne ze względu na zbiory budżetowe zwiększa $l$-sprawiedliwość.

Ponadto zestawiając twierdzenie $1 \mathrm{z}$ twierdzeniem 5, otrzymujemy wniosek, że zmiany innowacyjne połączone ze zmianami kumulatywnymi zachowują poziom $d p$-sprawiedliwości oraz zwiększają poziom $l$-sprawiedliwości. Formalnie zapisujemy:

Wniosek 1. Przy założeniach twierdzenia 1 zachodzi:

1) $E_{p} \leq_{d p} E_{p}^{\prime}$,

2) $E_{p}<{ }_{l} E_{p}^{\prime}$.

Dowód. W pierwszym punkcie twierdzenia wystarczy zauważyć, że silne rozszerzenie kumulatywne $C \subset_{c}^{\beta} C^{\prime}$, podobnie jak założenie $C \subset_{c} C^{\prime}$ w dowodzie twierdzenia 1, gwarantuje, że sytuacja najmniej uprzywilejowanego konsumenta w ekonomii $E_{p}$ nie ulega pogorszeniu. Warunek drugi jest bezpośrednią konsekwencją twierdzenia 5.

Warto zauważyć, że otrzymane rezultaty stanowią zarazem pozytywne rozwiązanie problemu respektowania efektywności Pareta systemu gospodarczego w warunkach rozwoju innowacyjnego. W artykule nie wyczerpano podjętej tematyki aksjomatycznej analizy sprawiedliwości dystrybutywnej J. Rawlsa w modelu Arrowa-Debreu w kontekście ewolucyjnej ekonomii Schumpetera. Pewne wyniki badań w tym zakresie można znaleźć w publikacji [Innovative Economy... 2013]. Dotyczą one m.in. analizy sprawiedliwości dystrybutywnej w dwuokresowym modelu dochodu z własnością jednoosobową.

\section{Literatura}

Brighouse H. [2007], Sprawiedliwość, Wydawnictwo Sic!, Warszawa.

Ciałowicz B., Malawski A. [2011], The Role of Banks in the Schumpeterian Innovative Evolution: An Axiomatic Set-up [w:] Catching Up, Spillovers and Innovation Networks in a Schumpeterian Perspective, eds A. Pyka, M. da Derengowski Fonseca, Springer-Verlag, Berlin-Heidelberg.

Debreu G. [1959], The Theory of Value, Wiley, New York.

Hammond P.J. [1976], Equity, Arrow's Condition, and Rawls' Difference Principle, „Econometrica”, vol. 44, nr 4 (July), http://dx.doi.org/10.2307/1913445. 
Innovative Economy as the Object of Investigation in Theoretical Economics [2013], ed. A. Malawski, Cracow University of Economics Press, Cracow.

Karp J. [2004], Sprawiedliwość społeczna. Szkice ze współczesnej teorii konstytucjonalizmu i praktyki polskiego prawa ustrojowego, Księgarnia Akademicka, Kraków.

Kot M.S., Malawski A., Węgrzecki A. [2004], Dobrobyt społeczny, nierówności i sprawiedliwość dystrybutywna, Wydawnictwo Akademii Ekonomicznej w Krakowie, Kraków.

Malawski A. [1999], Metoda aksjomatyczna w ekonomii, Ossolineum, Wrocław.

Malawski A. [2008], Distributive Justice and Schumpeterian Innovative Evolution - An Axiomatic Approach in the Context of Social Cohesion, Proceedings of the Fourth International Conference Wrocław 2008: Quality of Life Improvement through Social Cohesion, Wrocław.

Malawski A., Mrówka J. [2004], Aksjomatyczna analiza ubóstwa i sprawiedliwości dystrybutywnej w gospodarce rynkowej [w:] Postępy ekonometrii, red. A. Barczak, Prace Naukowe Akademii Ekonomicznej w Katowicach, Katowice.

Malawski A., Woerter M. [2006], Diversity Structure of the Schumpeterian Evolution. An Axiomatic Approach, Arbeitspapiere/Working papers of the Swiss Institute for Business Cycle Research, No 153, October 2006, Zurich, http://dx.doi.org/10.2139/ ssrn.952628.

Mrówka J. [2009], Ubóstwo, sprawiedliwość dystrybutywna i swoboda wyboru w modelach równowagi ogólnej, Uniwersytet Ekonomiczny w Krakowie, rozprawa doktorska finansowana z grantu o numerze NN111 454534.

Porębski C. [1999], Umowa społeczna. Renesans idei, Znak, Kraków.

Rawls J. [1971], A Theory of Justice, Harvard University Press, Cambridge, MA.

Rawls J. [1994], Teoria sprawiedliwości, Wydawnictwo Naukowe PWN, Warszawa.

Rawls J. [2001], Justice as Fairness, Harvard University Press.

Roemer J.E. [1996], Theories of Distributive Justice, Harvard University Press, Cambridge.

Schumpeter J. [1912], Theorie der wirtschaftlichen Entwicklung, Leipzig.

Schumpeter J. [1934], The Theory of Economic Development, Harvard University Press, Cambridge, MA.

Schumpeter J. [1960], Teoria rozwoju gospodarczego, PWN, Warszawa.

Sen A.K. [1970], Collective Choice and Social Welfare, Holden Day, San Francisco.

Sen A.K. [1992], Inequality Reexamined, Oxford University Press, Oxford.

Sen A.K. [1999], Development as Freedom, Alfred A. Knopf, New York.

Sen A.K. [2000], Nierówności. Dalsze rozważania, Znak, Kraków.

Sen A.K. [2002], Rozwój i wolność, Wydawnictwo Zysk i S-ka, Poznań.

\section{An Axiomatic Analysis of John Rawls' Distributive Justice in the Arrow-Debreu Model}

The paper presents the concept of John Rawls' distributive justice and its axiomatic analysis in a market economy represented by a Debreu economy with private property. The interpersonal comparisons introduced allow for the designation of the least advantaged individuals and for the rules to be defined for the difference principle. This principle is then generalised to the leximin. The defined relationships of justice, independent of 
the state economy, characterise the model of the economy. This allows for the construction of multi-range relational systems with characteristics specifically defined. Suitable defined extensions of systems and their characteristics illustrate Schumpeter's evolutionary economics. In this perspective, we may ask what conditions guarantee the preservation of the defined relationships of distributive justice. The answer may be found in the cumulative extension of a Debreu economy corresponding to Schumpeterian circular flow. The innovative changes, which are the basis for economic development, while sustaining cumulativity, preserve the level of justice in the sense of the difference principle and increase the level of justice in the sense of leximin.

Keywords: distributive justice, John Rawls, the difference principle, leximin. 